\title{
The Influence of Space on the Sense of Security on the Part of the Local Community. On the Basis of Bydgoskie Przedmieście District in Toruń
}

Wpływ przestrzeni na poczucie bezpieczeństwa społeczności lokalnej. Na przykładzie osiedla Bydgoskie Przedmieście w Toruniu

\section{- Abstrakt •}

Celem artykułu jest wskazanie głównych determinantów, które wpływają na bezpieczeństwo przestrzeni, a także implementacja rozwiązań, które oddziałują na poprawę jej bezpieczeństwa. Polem badawczym jest miasto Toruń, ze szczególnym uwzględnieniem wyjątkowo mocno rozwijającej się na przełomie XIX i początku XX wieku dzielnicy Bydgoskie Przemieście.

Słowa kluczowe: bezpieczeństwo społeczności lokalnych, Bydgoskie Przemieście, wybite szyby, gettyzacja przestrzeni

\section{- Abstract •}

The goal of this paper is to point out the main determinants which have an impact on the space security as well as the implementation of the solutions which contribute to the improvement of its security. The area of research is Torun, with the special attention paid to the particularly rapidly developing district of Bydgoskie Przedmieście, the said development taking place at the turn of the $19^{\text {th }}$ century.

Keywords: the security of local communities, Bydgoskie Przedmieście, broken windows, ghettoization of space

An important factor in perceiving security of the local community is the influence of the environment on the inhabitants' perception ${ }^{1}$. Studying space, one can take

${ }^{1}$ By the security of local communities, the author understands the state of the lack of objective dangers to the community, the community inhabiting a small area and is interconnected by strong particular personal bounds, by the sense of emotional attachment to the place they dwell in, to its tradition history and also by the care and attention towards multi-dimensional security in the said area. By security, following Misiak, the author understands: the state of the lack of threat towards any legal good of man, which allows an individual to function well within the society and in par- 
heed of many of its elements related to security. These comprise:

- type of development;

- the idiosyncrasies of green areas;

- functionality of the space;

- the relations between the public and private sector;

- social groups inhabiting the space.

The purpose of the present paper is to indicate the main determinants which have an impact on the security of space as well as the implementation of the solutions contributing to the improvement of its security. The research area is Torun, with the special attention paid to Bydgoskie Przedmieście district, the district being located in the western part of the city and being inhabited by over 25 thousand people. It is recognized that in this area there are manifestations of hooliganism and vandalism, and the district itself is fraught with contrasts. Apart from frequent deliberate damages inflicted on the walls or breaking windows, there are also assault and stealing women's bags. Furthermore, there are such spots that people are afraid, especially in the evenings, to go through because drunk and violent people linger there. As was reported by the press, in the district, there are some inhabitants who are unable to pluck up their courage to leave their houses in the evening (Spandowski, 2009). The district appears to be potentially attractive for tourists, which is mainly due to its historical development and the green surrounding it. The district is a combination of modernity and history.

It is said that Przedmieście is an "atmospheric spot". What one should be especially proud of is its beautiful architecture, which is a rarity indeed, e.g. $19^{\text {th }}$ -century wattle-and-daubed and wooden development; as well as eclectic and Art Nouveau tenant houses and modern villas. Still, the district is getting transformed. Wealthy people move in there and so-far communal property is becoming the property of tenants' association.

The hypothesis stated in the present text assumes that we continuously encounter the process of ghettoization ${ }^{2}$ in Polish cities and that in the process of creating secure spaces the social participation plays too little a role. Side hypotheses have it

ticular, to maintain life, good health, property and the freedom of taking advantage of all personal rights an individual is entitled to. All the above entitlements are guaranteed by the Constitution and other legal precepts for the enforcement of which the relevant authoritative bodies endowed with the relevant powers are responsible (Misiak, 2008, p. 16).

${ }^{2}$ Ghettoization - in a sociological sense - is nothing else but the process of the emergence of ghettos, that is homogenous areas. Some scholars point out that the key role in the said process is played by the emergence of physical barriers, of one sort of citizens being fenced off from the others. Further on the subject: Szczepański, Ślęzak-Tazbir, 2007, p. 29-92. 
that it would be the theory of "broken windows"3 that would have the impact on the security of the district. The other factors that would exert some influence are the changes in lighting of the streets, squares and park in the said area as well as restoring a police station.

One should answer the question of what are the roles of a properly built space in order to ensure security to the citizens and to improve the quality of their lives through:

1. "restricting the entrance to specific zones for unauthorized persons;

2. limiting the number of acts of vandalism;

3. reducing theft and riots;

4. creating the environment unattractive to an intruder or assaulter, e.g. through eliminating comfortable hiding places;

5. strengthening the identity and social bonds among the inhabitants;

6. restricting the traffic, and lowering the noise thereof;

7. creating the spots conducive to leisure;

8. strengthening the sense of responsibility among the inhabitants for their own security and for the common good" (Lisiecki, 2011).

Nowadays, regarding the dangers occurring in this space, one can realize that what is more vulnerable to the public-good-related issues are the high-density agglomerations. Although this sort of development does not almost occur in the area of Bydgoskie Przedmieście, in order to better sketch the spheres of insecurity in cities it is worthwhile to mention that dysfunctionality appears much more frequently in large residential complexes, colloquially referred to as blokowisko [housing estate]. Large residential complexes became a part of the cities due to the burgeoning trends in post-World-War-II architecture - it concerned mainly the modern architecture, which proved to be dominating until the first half of the seventies. What played a major role in the trends of architecture was the revolutionary Soviet architecture and also Bauhaus disseminated in Germany. The architect who played a very important role in popularizing the type of architecture of raw concrete, the task of which was to ensure as many flats as possible in as little space as possible for the society right after the World War II, the said sort of architecture serving as a benchmark to forthcoming forms of residential complexes, was Le Corbusier.

${ }^{3}$ If there is a broken window in a factory or in the office, the passer-by who had noticed that, will come to the conclusion that nobody cares about this state of affairs and that nobody is responsible for the condition of the buildings. After a while, there will appear such people that will start throwing stones at the remaining windows. Afterwards, there will be no windows left and the pedestrian will come to the conclusion that nobody is responsible for the building and neither for the street he is just "walking by" (Kelling, Coles, 2000, p. 10). 
In Poland, as early as before the war, there emerged modern districts such as, to have but one example, Warszawska Spółdzielnia Mieszkaniowa, but application of large-panel structure in our country boomed in the fifties - the block of flats in Jelonki in Warszawa and Nowa Huta (Słodczyk, 2010, p. 17-19). Large residential complexes contributed to the atomization of the society and the space itself of the districts of such a type disturbed some part of interpersonal relations. What also emerged in the nineties was the subculture referred to as blokersi. This youth most of their time used to spend at the staircase of their block of flats or at the nearby bench together with their friends. The culture of blokersi was most often based on hip-hop, breakdance and on creating visual tokens on concrete-made walls in the form of tags and graffiti. Among blokersi, a very important element marking their identity was sport - oftentimes football - which became a distinctive feature among kibole [hooligans]. When it comes to other physical activities, one should mention body-building-related activities, that is local gyms as well martial arts and systems of combat. It is already said hip-hop that inclined its adherents towards a characteristic manner of moving and dressing. Its message also referred to the level of life and the issues connected therewith. Blokersi are known in their respective local districts also by the elderly; yet, as it often happens the local inhabitants are afraid of them when they see them in large groups. These days, the subcultures inhabiting housing estates are different. Blokersi were superseded with kibitzers; however, this group transcends the environment of large residential complexes. In Toruń, the disctricts of large-panel structures include: Rubinkowo I and II as well as "Na Skarpie" district. In the present paper, the author will focus only on the said Bydgoskie Przedmieście, in the terrain of which the blocks of flats of large-panel structure are sporadic; yet, some old tenant houses, being communal buildings, are also assemblages of youth, the youth spending time on the bench nearby.

In order to define security-related issues in the area of Bydgoskie Przedmieście, the author availed himself of two methods - survey method with the use of the questionnaire filled in during the interviews with the subjects being the inhabitants of Bydgoskie Przedmieście (120 subjects took part) - all in order to define the problem. The other method was the method of participant observation, which was the result of the results of the survey- all in order to verify the conclusions stemming from the survey. All the subjects included in the survey have lived in Bydgoskie Przedmieście for at least 3 years. In the survey, there took part 60 adult women and 60 adult men. The youngest subject was 21 , and the oldest 78 . Among the subjects, there were also such persons who inhabited the district for a short time, that is about 3 years; but there were also such people who have inhabited Bydgoskie Przedmieście for 30 years or even more. The average age of the subjects 
was 38 , and the average period of inhabiting the district was 18 years.

The division was made into age groups. The distribution of numeracy of particular age groups was as follows. The greatest percentage share fell on the people aged between 30-39 - there were 40 such people; people aged between 20-2930 such people; aged between 40-49 - 22 such people; aged between 50-59- 15 such people; and aged between 60-69 - 11 such people; and finally, people over $70-2$ persons. The author during the survey was aware of the fact that the sense of security is hard to define; yet, survey research was to point out to the author the realms of potential dangers.

It is worth noticing that the sense of security sets a benchmark to estimate the level of sensing danger. The concept of the sense (or the feeling) is defined as "recognizing certain facts or phenomena taking place in the surrounding environment as well as being aware of internal states: consciousness, sensation or impression". The state in which an individual is satisfied with his or her level of security and simultaneously does not experience any sense of danger while feeling calm and peaceful and possesses adequate resource to commence an action - all these conditions put together may be labelled as the sense of security. The sense refers to, as said above, to subjective sensations. It is contingent upon one's own psychological factors, beliefs and the appropriate evaluation of the social environment, the sense of subjecthood and the level of basic hope. What also has an impact on this sense are also life circumstances of a given person. Its subjective nature makes a person facing danger be able to state that he or she feels secure or experiences danger with the full social order being preserved. What is possible is also properly interpreting the premises and skillfully taking advantage of them in creating the faithful representation of the situation. A necessary condition here is the availability of all important information related to security, the information pertaining to the status quo of the environment and the willingness to cognize and analyse the data provided (Klamut, 2012). The sense of security is highly varied across individuals and contingent upon many stimuli; while doing local survey research, what will have some impact will be the fact whether a given subject lives permanently in a given area, and is, so to speak, "rooted" in this area; or whether he or she has inhabited it for a relatively short time. The perception of security also depends on the age of respondents, and also on the type of the structure of the building they dwell in large panel structure, communal tenant house or a gated neighbourhood. What is also not without significance is the time of the year in which the survey was conducted. The survey took place in the period between February and June $2017^{4}$.

\footnotetext{
${ }^{4}$ Arranging the research in time was mainly due to the survey research, the result of which -
} 
As mentioned above, the survey research was exclusively a basis for the observation-based research. When the subjects were asked the question whether they felt secure in Bydgoskie Przedmieście, the responses were distributed as follows.

- YES $-40 \%$ of respondents,

- NO $-60 \%$ of the respondents

When asked the question of which spot is the most dangerous in Bydgoskie Przedmieście (more than one answer was allowed to be provided), the respondents replied as follows:

- the majority of people regarded Park Miejski (66\%) as the most dangerous,

- Mickiewicza street (50\%),

- Bydgoska street $(36 \%)$,

- Piekarskie Góry (25\%),

- Koszary ułanów $(25 \%)-19^{\text {th }}$-century development between Mickiewicz and Asnyka streets.

Upon respondents' indicating potentially dangerous spots in Bydgoskie Przedmieście, the author, on the basis of conducted research, defined which elements had an impact on the sense of security of the neighbourhood's inhabitants.

- Lighting and visibility (60\%),

- the places rarely frequented by pedestrians (55\%),

- the people labelled as underclass occupying a certain $\operatorname{spot}^{5}(50 \%)$,

- the neighbourhood of derelict or heavily neglected houses (41\%),

- the lack of visual monitoring (36\%).

With regard to lighting and its influence upon security, one must state that the basic source of light are street lights - defined as sources of light in a light fixture together with a structure suspending it (a post, jib or overhang), the task of which is to illuminate streets, pavements and roads (also the avenues in parks) under the conditions of insufficient visibility - especially at nights, but also when under fog, heavy precipitation or when it's very cloudy, etc. - at the places in which there can be many persons, vehicles. Street lights are usually posted in cities and smaller towns at crossroads and along the streets; but also away from cities; e.g. along busy motorways, at junctures and railroad crossings. Modern street lighting is designed so as to minimize light pollution, that is to minimize a part of light stream pointing upward and sideward - this part of light stream does not serve to improve the visibility on the ground and it de facto wastes the energy that is uselessly beamed

according to the author - depends on the season. In winter, more people pointed at the influence of lighting as a factor related to the security in the area of the district.

5 The spot being usually defined as - communal residential building, in the close vicinity to off-licenses open at late evening hours. 
into the sky while also stymieing amateurish astronomic observations. For those purposes, the fixtures with the flat glass window are produced. In recent years, one started to fight the so-called light pollution because the incorrect location of the sources of light in people's properties, stadiums and architectonic buildings unfavourably influences the security in road traffic. This problem has started to be addressed since halogen lamps appeared (Czarnecki, Siemiński, 2004). Oftentimes, an improperly directed stream of light does not improve visibility; nay, it has a negative impact on visibility. The cause of light pollution is certainly too dispersed stream of light. When lamps are endowed with shades, then light is pointing downward. Yet, it should be mentioned that not only roadside lamps contribute to such an effect. It also results from the lighting in shop windows, car dealers, stadiums, commercial billboards, which all beam large rays of light - not being directed in a particular direction but rather dispersed. Undoubtedly, lighting has a bearing on how we perceive security. During research conducted in winter, it was the case that especially the vicinity of "Piekarskie Góry" was poorly illuminated. Certainly, the weather changes in June, but the surroundings of this place still testify to a long period of neglect.

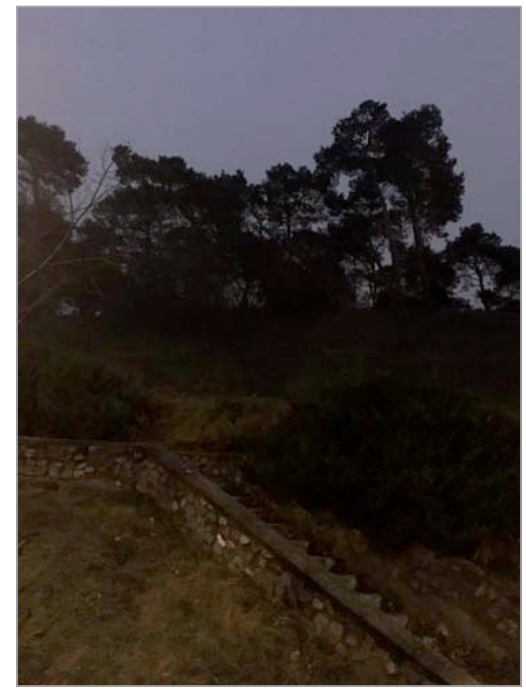

The fragment of "Piekarskie Góry" - at 19:00 in February 


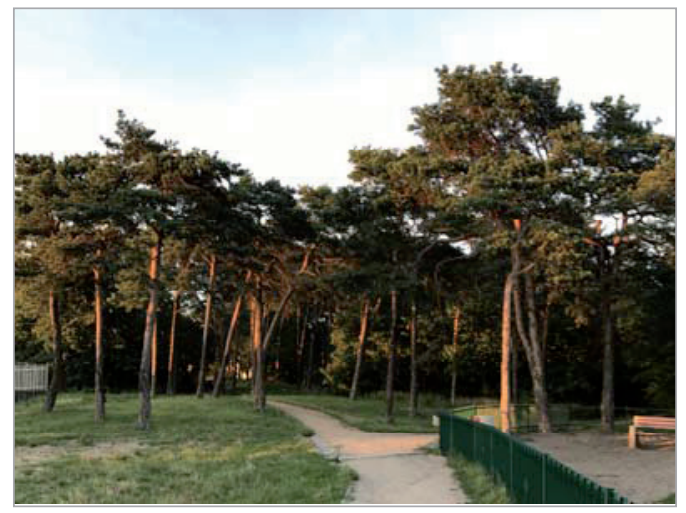

The fragment of "Piekarskie Góry" - at 19:00 in June

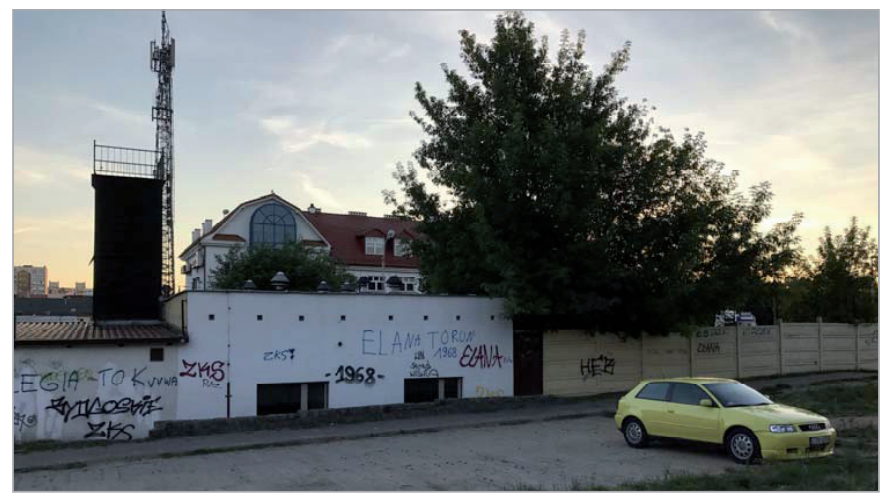

A passage towards "Piekarskie Góry"

It is hard to imagine that the avenues in the parks were illuminated as well as promenades in city centres; however, the lack of lighting coupled with the absence of a police station contributes to the fact that the parks located in Bydgoskie Przedmieście are judged by its inhabitants as dangerous, especially during autumn and winter. The question arises: is it worthwhile to endow the neighbourhood without a police station with one such station? What follows from the research is that $67 \%$ of the respondents are in favour of setting up a police station there $-36 \%$ of the respondents emphasized their frank acknowledgement by choosing the answer 'definitely yes' and $31 \%$ of them answered 'yes', In the inhabitants' opinion, there is a need for a police station - among others - in the cases calling for quick intervention and when it comes to the general order in the streets. However, $30 \%$ of the respondents believe that a police station is not needed and 
its presence in this neighbourhood would not change anything. This answer was ticked by the people who feel safe in this neighbourhood, especially young people (up to 30 years old). It was only $3 \%$ of the respondents that did not express any opinion on the matter.

Apart from lighting, what contributes to the sense of insecurity is devastated environment, derelict tenant houses or the visible signs of vandalism. Devastated space fits the theory of broken windows. Conspicuous lack of responsibility for certain buildings, at least on the part of a private owner and also on the part of self-government makes a given house, fence or a small architecture get damaged by vandals. In the area of the scrutinized district, these places are located in the streets indicated by the inhabitants in the survey. At Bydgoska 50, there is a historical building getting damaged. Despite the attempts to endow the place with a new useful character, after the eviction of the inhabitants, the building got clearly degraded month by month. Such buildings are plentiful in the area of the district.

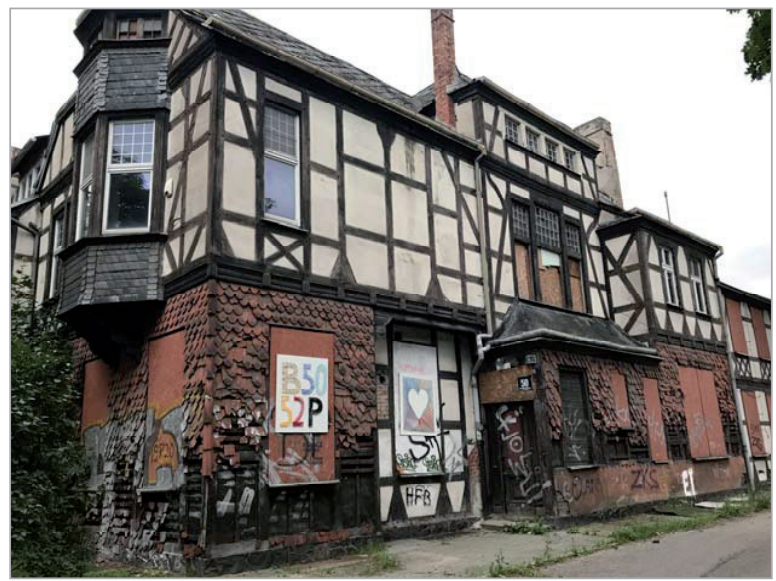

The building at Bydgoska 50 - the picture taken in May

The fact that the buildings are neglected is evidenced by the most representative street of the neighbourhood - Mickiewicza. The dangers in the area thereof were pointed out also by the inhabitants of Bydgoskie Przedmieście. At the streets, there are both private properties and the properties belonging to housing co-operative. What is neglected to the highest degree though are the terrains belonging to Zarząd Gospodarki Mieszkaniowej Urzędu Miasta Torunia [Housing Management of the City Council of Toruń]. At the said street, what is visibly missing is the lack of revitalizing actions, which contributes to the degradation of 
the environment and hence to the decreased sense of security on the part of the inhabitants.

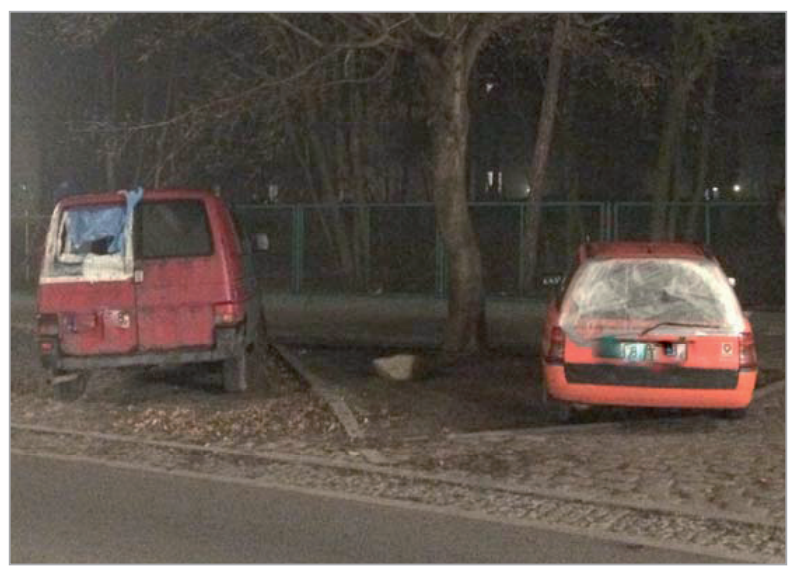

Cars parked on Mickiewicza Street - March

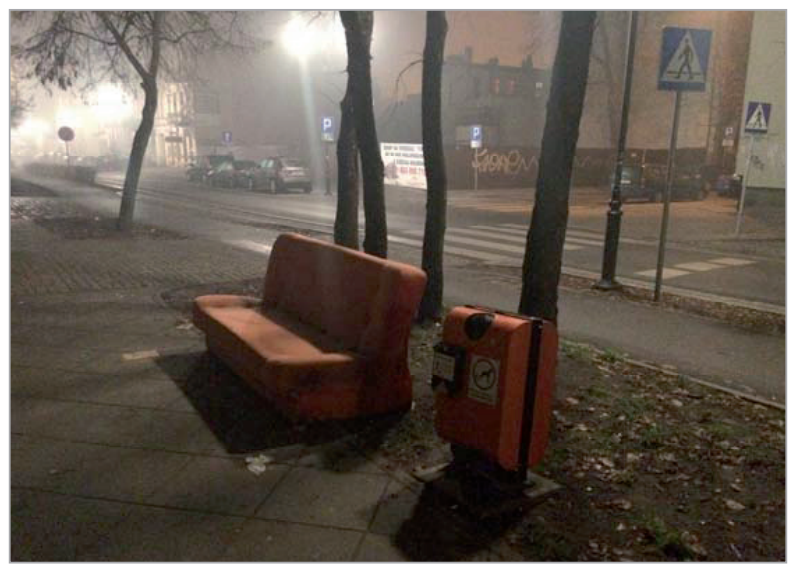

Mickiewicza Street - March

The pictures show that the main street of the district, Mickiewicza, due to a few processes taking place in its area (as far as it's public sphere), may have a negative impact on the sense of security of its inhabitants.

Bydgoskie Przedmieście district is also subject to ghettoization. In its area there are places especially of wattle-and-daubed structure, in which the said process occurred, the process being conceived of as the emergence of ghettos, that is socially homogoneous areas contirubuting to social stratification. This process ap- 
plies especially to the inhabitants of the devlopment dating back to the turn of the $19^{\text {th }}$ century, as the already mentioned Koszary ułanów, which is located between Mickiewicza and Asnyka streets. The neighbourhood of a few wattle-and-daubed buildings has a rather bad reputation; oftentimes, public protection personnel intervenes in the houses situated there. What is more, this spot is considered dangerous. In the area of Bydgoskie Przedmieście, who is also ghettoized are the people inhabting gated neighbourhoods. This process is referred to as social polarization manifested by spatial division, which contributes to the emergence of "dualistic structure of the city"; and what became its special mark are separated elitist residential enclaves (Kłopotowska, 2010).

Summarizing the research, both survey and the later participant observation proved that the estimation of security of the neighbourhood to a large degree depends on such elements as lighting or the care about the look of the buildings, squares and parking lots. What is still noticeable is the process of ghettoization, contributing to the disintegration of the inhabitants of a given environment. Furthermore, in the districts so impoverished as Bydgoskie Przedmieście, the mechanism of social control does not work sufficiently well, the mechanisms being - among others - "eyes of the street" or the activities aimed at preventing the emergence of "broken windows". However, what takes place is a slow process of gentrification. Particapant observation conducted in the period from February to June 2017 led up to the confirmation of the conclusions drawn from the survey conducted among the inhatitants. An important factor, being indicated during the survey and supposed to improve security - or rather - to improve the sense of security, would be to restore a police station in the neihgbourhood.

Most of all, from the survey there follows the conclusion that the most fundamental factor that would contribute to the sense of security will be increasing social participation in maganing the area, ordering degraded areas and thwarting the processes of ghettoization as well introducing changes of the kind of lightining in the places dedicated to recreation, which would contribute to their increased availability for the inhabitants and would surely change the inhabitants' perception of them.

\section{References:}

Czarnecki, B., Siemiński, W. (2004). Ksztattowanie bezpiecznej przestrzeni publicznej. Warszawa: Difin.

Kelling, G.L., Coles, C.M. (2000). Wybite szyby: Jak zwalczyć przestępczość i przywrócić tad w najbliższym otoczeniu. Poznań: Media Rodzina. 
Klamut, R. (2012). Bezpieczeństwo jako pojęcie psychologiczne. Ekonomia i Nauki Humanistyczne, 286 (19), 41-51. DOI: 10.7862/rz.2012.einh.26.

Kłopotowska, A. (2010). Czynnik „obronności” we współczesnej architekturze zespołów mieszkalnych. Budownictwo i Architektura, 6 (1), 51-61.

Lisiecki, M. (2011). Zarządzanie bezpieczeństwem publicznym. Warszawa: Wydawnictwa Akademickie i Profesjonalne.

Misiak, A. (2008). Administracja porzadku i bezpieczeństwa publicznego. Zagadnienia prawno-ustrojowe. Warszawa: Oficyna Wydawnicza Łośgraf.

Słodczyk, J. (2010). Geneza i rozwój osiedli blokowych. In: I. Jażdżewska (ed.), Osiedla blokowe w strukturze przestrzennej miast (p. 11-25). Łódź: Wydawnictwo Uniwersytetu Łódzkiego.

Spandowski, S. (2009). Piją, palą, klną i niszczą. Nowości, 136, 7.

Szczepański, M.S., Ślęzak-Tazbir, W. (2007). Między lękiem a podziwem: getta społeczne w starym regionie przemysłowym. In: B. Jałowiecki, W. Łukowski (d.), Gettoizacja polskiej przestrzeni miejskiej (p. 29-52). Warszawa: Wydawnictwo Naukowe "Scholar”, Wydawnictwo Szkoły Wyższej Psychologii Społecznej “Academica”. 